\title{
Impact of Organizational Justice on Workplace Deviance with Mediating Effect of Job Satisfaction in SMEs of Malaysia
}

\author{
Dr. Ali Abbasi*,F.Baradari, Hamzeh Sheghariji Dr.Javad Shahraki \\ Azman Hashim International Business School, Universiti Teknologi Malaysia,
}

\begin{abstract}
The efficiency of organizations and performance of employees in the workplace in such a competitive global economy and businesses require some factors that enhance the performance and job satisfaction of employees in the workplace. The aim of this study is to investigate the role of job satisfaction in the relationship between organizational justice and workplace deviance. A survey questionnaire was distributed online to 143 employees in various enterprises in Malaysia of which 103 responded. The findings show that distributive Justice affects workplace deviance through job satisfaction. Therefore, if avoidance of workplace deviance is a top priority for a manager, it is important to formulate policies and practices that help to enhance interactional justice and then distributive justice perceptions, while procedural justice is not a salient factor affecting employee perceptions. Preventing or remedy deviance may require both individual and organizational change. The managers would therefore be well advised to remedy inequities in the system if they really exist or to clear misperceptions of inequities if this is actually the case. Preventing or remedying deviance may require both individual and organizational change. The result of this research could be useful for organizations and might help them to enhance organizational justice to decrease deviance in workplace.
\end{abstract}

Keywords: workplace deviance, job satisfaction, organizational justice

DOI: $10.7176 / \mathrm{EJBM} / 12-17-06$

Publication date:June 30th 2020

\section{Introduction}

Deviance in workplace become one of the main issues that impact on outcomes and efficiency of employees in organization. There are many of reasons for workers to be treated inappropriately in the workplace, but this leads to increase cost and decrease efficiency (Alias \& Rasdi, 2015).. Many organizations recognize the impact of deviance on their outcomes and understand that minimizing workplace deviance is necessary for them to remain competitive in the market. The efficiency of an organization and maximum outcomes of employees in a workplace in such a competitive market requires some factors that impact the enhancement of the performance and job satisfaction of employees in the workplace. (Abbasi \& Wan Ismail, 2018).

Workplace deviance is considered as one of the most costly behaviors against the productivity and efficiency of employee in the workplace. Organizational justice has an impact on minimizing or preventing deviance in the organization. The tendency of behavioral experts is to study from an employee viewpoint in the last four decades. Although the relationship and impact of organizational justice, distributive, interactional and procedural justice, job satisfaction and workplace deviance are explored individually by numerous researchers, knowing the impact of these variables on workplace deviance require more study and effort (Alias \& Rasdi, 2015). Job satisfaction and Organizational justice were much explored explicitly in the literature of management, but deviance in the workplace was not as focused as much as organizational justice (Bodla \& Danish, 2009). Studies in deviance in the workplace began approximately three decades ago. In these thirty years, plenty of research was conducted on deviance behavior in an organization, which introduced numerous components and a variety of outcomes (Bennett \& Robinson, 2003).

Organizational justice, which is divided into distributive, procedural and interactional justice, have an important role in the enhancement of the outcome of employees (J. Greenberg, 1990). Based on Alias and Rasdi (2015) organizational justice, is one of the most predictors of workplace deviance. In practical perspective, since WDB covers a wide range of organizational cost, recognition of WDB is vital in each organization to increase efficiency of organization. By increasing justice and fairness in organizations, those employees who are prone to deviance in organization would decrease. In other words, many components of dysfunctional and other sort of deviance would minimize in the workplace (Kim \& Chung, 2019).

Bennett and Robinson (2003) deduce that the workplace deviance is one of the salient problems in organizational behavior. The variety of deviance and numerous reasons that lead to dysfunction in the workplace make this issue one of the important topics in organizational behavior. The relationship and impact of distributive justice, procedural justice, interactional justice, job satisfaction and workplace deviance were explored individually by numerous researchers (Colquitt, Conlon, Wesson, Porter, \& Ng, 2001). The collective impact of these variables on workplace deviance still requires more study and work (Colquitt, 2001).

The enormous cost of deviating in the workplace makes this issue one of the vital challenges in the majority of organizations. However, most of the deviance cases are not revealed or highlighted in media. Workplace 
deviance in Malaysia has increase sharply, and many cases of corruption and bribery have been revealed in Malaysia, such as Malaysian airline 2009 and 1MDB. Recently, the 1MDB has become one of the most challenging cases in Malaysia, which has been announced by foreign media. The role of the division is in line with Section 7 (a) and (b) under the Malaysian Anti-Corruption Commission (MACC) Act 2009. The MACC was modeled after top anti-corruption agencies, such as the Independent Commission Against Corruption (Hong Kong) and the Independent Commission Against Corruption (Australia). Based on Malaysian Anti-Corruption Commission MACC, the number of corruption cases increased from 552 in 2014 to 841 in 2019.

Therefore, the current study attempts to explore the impact of organizational justice to workplace deviance with mediate of job satisfaction and to verify whether job satisfaction meditates the correlation between organizational justice and workplace deviance. The result of this research could be useful for organizations and might help them to enhance organizational justice to decrease deviance in the workplace. It provides broad information about the reason for deviance and the consequences of that, which mostly leads to increase productivity and efficiency of the organization.

The result of this study helps the managers and supervisors in monitoring the employees to find any dissatisfaction and precaution against unfairness among labors. This research gives an insight of the type of organizational justice that is salient for each construct and allows the management of organizations to take appropriate actions to improve conditions at the workplace and prevent deviance in the organization. The scope of this study is more concerned about deviance in the workplace and most of the questionnaires were filled by employees of SMEs in Malaysia. The respondents include all employees who work in Malaysia.

\section{Theory and Hypotheses}

Social exchange theory explained the behavior and attitudes exchanged between individuals such as involvement and exchange with supervisors, colleagues, organizations and teams, interactions along with workplace relations (Shore et al., 2009). The main idea in social exchange theory is that parties enter into and maintain exchange relationships with others with the expectation that doing so will be rewarding (Blau, 1968).

\subsection{Organizational Justice}

Organizational justice includes distributive, procedural and interactional justice and the behaviors in an organization such as payment satisfaction, job performance, reaction to organizational grievance systems and performance appraisal (Cole, Schaninger, \& Harris, 2002).

The broad idea behind organizational justice is about fairness in the workplace. According to Cohen organizational justice is a well-established antecedent of a variety of behaviors and organizational outcomes that explain the power of justice-related phenomena (Cohen-Charash \& Spector, 2001).

Many research show that organizational justice influences job satisfaction (Kulas, McInnerney, DeMuth, \& Jadwinski, 2007). Also, a few research are conducted on the effect of organizational justice on outcomes and productivity of the organization (McFarlin \& Sweeney, 1992). Some research asserts that the organizations tend to behave appropriately with their own employees. Therefore, the issue of the organization is how to distinguish the appropriate treatment as there are differences in the perception of justice and fairness even between two coworkers. Sometimes in the perception of one person, one behavior is fair, but the other person considers it inappropriate. In general, people are egocentric or self-serving. They see allocations or procedure favoring themselves as fair (Everton, Mastrangelo, \& Jolton, 2005).

Conlon and Meyer (2005) evaluated how employees behave based on perception of their fairness in the organization. They found that the main concern of organizational justice is regarding employee activeness and productivity in the organization. They also distinguished the result of rewards or punishments and dispatching in the organization (Conlon, Meyer, \& Nowakowski, 2005). The relationship between organizational justice and commitment and trust is positive among employees in an organization (Alexander \& Ruderman, 1987; Cropanzano $\&$ Folger, 1991). Some researchers are concerned about justice perception in an organization, which enables them to explain about many issues in organization (Cropanzano, Rupp, Mohler, \& Schminke, 2001).

On the other hand, some studies proved that there is a correlation between organizational injustice and sexual harassment, when the justice decreases the rate of sexual harassment increase in workplace (Rudman, Borgida, \& Robertson, 1995). Based on previous research, organizational justice clusters in three main groups of procedural, distributive and interactional justice (Guh, Lin, Fan, \& Yang, 2013). Based on research of Rice, Taylor, and Forrester (2020) organizational justice and inclusion theories to demonstrate that abusive supervision can be interpreted as an unwelcoming experience that ultimately has the ability to turn employees into poor organizational behavior. Organizational justice has made contributions to the inter-organizational literature by highlighting the effects of justice perceptions on behavioral, attitudinal, and organizational outcomes (Bouazzaoui, Wu, Roehrich, Squire, \& Roath, 2020) 


\subsection{Job Satisfaction}

Job satisfaction is a positive feeling about one's job resulting from an evaluation of its characteristics. There is a fact that an employee's job is more than just the obvious activities of shuffling paper, writing programming code or working with big machines in a factory or many others. The job needs communication with colleagues and bosses, follow the organizational rules and policies, meeting performance standards and living with working conditions that are often less than ideal. This means that an employee's assessment of how satisfied he or she is with the job is a complex summation of a number of discrete job elements (Robbins, Judge, Millett, \& Boyle, 2013). There are many fundamentals which could influence job satisfaction in the workplace. In this research like personality, loyalty and efficiency of employees in organization (Robbins et al., 2013). It is strived to perceive the general perception of job satisfaction and some common essential factors that have more relation to organizational justice and workplace deviance.

It is a fact that employees' loyalty to organization increases with job satisfaction, normally employees who are satisfied with their job are enthusiastic about their job and also have positive behaviors in their workplace. Furthermore, they determine that other jobs cannot give them better opportunities compared to an existing job, the level of job satisfaction and employee effectiveness in the workplace have a positive relation (Cote \& Heslin, 2003). This personality of the workers and environment of organization, rewards and promotion, job security and appropriate behavior of co-workers in the organization has a vital role in job satisfaction. When an organization allows the employees to be involved in decision making in the organization, the level of trust increases and morality of employees also enhances, leading to job satisfaction (Yip \& Rowlinson, 2009).

One of the main factors that enhance efficiency and success of employees in the workplace is job satisfaction, which is more dependent on human resource management in the organization. (Crossman \& Abou-Zaki, 2003). Based on the work of some researchers it can be concluded that the role of appropriate environment of the workplace and respect to the employees' impact on increasing the organization productivity. On the other hand, dissatisfied respondents tend to cite extrinsic factors such as supervision, pay, company policies and working condition (Ladebo, Awotunde, \& AbdulSalaam-Saghir, 2008). Moreover, research has suggested that job dissatisfaction is related to measures of deviant behaviors (Bennett \& Robinson, 2000).

\subsection{Workplace Deviance}

Some researchers like Bennett et al., (2000) divided the deviance in two groups. The first one, organizational deviance, is more concerned about direct behavior in organizations which consists of picking up the product or tolls, intentionally damage or disrupt the equipment in the organization, strong reaction to any unpleasant action deviance. The second one, interpersonal deviance, which is related to employee of an organization, comprises of verbal abuse, mobbing and sexual harassment and jeopardizing the colleagues (Bennett \& Robinson, 2000).

Deviance in organization has different characteristics, but most of the times they have negative results and consequences for the organization, which sometimes influence the productivity and efficiency of employees. It is proven that those who spent much time in an organization realize that people often behave in a way that violates established norms. For example employees are not focused enough during the work. Envy among employees is one of the internal feelings which happens in many situations. An employee is angry with his/her co-worker, who gained some rewards that she or he has a strong desire to obtain, can lead to deviance. Sometimes some small matters in organizations such as a bigger room or even an extra table can cause hateful deviance behavior among employees. The envious employee could operate some inappropriate behavior spitefully like talking negatively about the colleague to spoil his or her image, distorting others successes and positively explained his own accomplishments. It is proven that those employees who have negative feelings and emotions against the organization prone to deviant attitude such as employee withdrawal, tardiness, sabotage, dishonesty, dysfunctional and counterproductive behavior in the workplace (Bennett \& Robinson, 2000).

In order to recognize the deviance behavior in the organization, first, we should perceive the norm of organization and society. Second, the deviance behavior threatens the organization or employees or even both. Robinson and Bennett's (1995) researched about the ethical aspect of deviance and how deviance is destructive in the organization for employees. Generally, organizational researchers divided deviance behavior into four major groups, property deviance, personal deviance, political deviance and production deviance.

Few research have shown that the participation in some groups would enhance the probability of deviance attitude. They conclude that some kind of deviants in the workplace just occur in groups. In some other research, it is shown that when group working is compared with individual working, those who work in a group were more likely to lie, cheat, and steal (Robinson \& Bennett, 1995). On the other hand, many other research show that if the employees are members of one group, they are afraid to be caught for stealing something from the organization. Despite that, the impact of group working in other type of deviance is positive. Thus, group policy and regulation can affect workplace deviance (Robbins et al., 2013). 


\subsection{Organizational justice and workplace deviance}

According to some researchers, the ability to perceive workplace deviance depends on recognizing the components of organizational justice, and emphasizing how different types of injustice in an organization lead to deviance in the workplace (Alias, Ismail, \& Abu Samah, 2013; Alias \& Rasdi, 2015; Greenberg, 1990; Ouyang, Sang, Li, \& Peng, 2015).

In essence, it can be concluded that there is a negative correlation of deviance with organizational justice (Colquitt, Scott, Judge, \& Shaw, 2006). Negative relation of deviance and justice was also established in a metaanalysis research by (Berry, Ones, \& Sackett, 2007). The recent research on organizational justice from correlation analysis has shown organizational justice negatively correlated with workplace deviance (Mahmud, Kenny, Zein, \& Hassan, 2015). Furthermore, Faheem and Mahmud (2015) demonstrate that organizational justice are negatively correlated with workplace deviance.

Furthermore, Faheem and Mahmud (2015) demonstrate that organizational justice are negatively correlated with workplace deviance. According to some researchers, the ability to perceive workplace deviance depends on recognizing the components of organizational justice and emphasizing how different types of injustice in an organization lead to deviance in the workplace (Ouyang et al., 2015). Based on the social exchange theory, employees tend to reciprocate with destructive behavior when the perceptions of justice in the organization are low. Furthermore, research on organizational behavior declare injustice in the workplace can be the reason of inappropriate behavior in an organization and also can lead to a variety of deviance in the organization (Alias \& Rasdi, 2015).

The study indicates that organizational factors play a critical role in shaping the workplace deviance behaviors of hospitality employees (Chen \& King, 2018). The study H Hany, M Hassan, and MM Badran (2020) showed that overall nurses' perceptions of organizational justice and workplace deviance are lower than the average. Organizational justice significantly related negatively to workplace deviance. The vital impact of deviance in the social sciences and the applications of the concept in organizational behavior was also established in a metaanalysis research by (Lugosi, 2019).

One of the recent research shown that justice differentially impact on the quality of employee and employeecoworker relationships, underlining the relevance of considering both supervisors and coworkers as sources of justice (Gerlach, 2019). Hence, the reviews of the above literature that highlight and rely on social exchange theory organizational justice have an impact on workplace deviance; therefore, the following hypothesis are proposed;

Hypothesis 1: There is a negative relationship between organizational justice and workplace deviance.

\subsection{Job Satisfaction and Workplace Deviance}

The level of job satisfaction in organizations can explain some specific behaviors, like substance abuse, stealing at work, tardiness and disproportionate socializing. These behaviors could be indicators of a broader syndrome called deviant behavior in the workplace. Many studies have proven that some employees do not like their work environment even if they sometimes react on it (Hackman \& Oldham, 1976). It is not easy to forecast exactly how employees will respond or act, but most of the time it is unpleasant for the organization. One employee might quit the job; another might be dysfunctional in the workplace (Robbins et al., 2013). The best solution for employees who want to control the undesirable consequences of job dissatisfaction is to attack the source of the problem of dissatisfaction rather than trying to control the different responses.

Some research described, employees who encounter dissatisfaction in the organization become displeased worker, that absenteeism among displeased worker is higher than normal workers (Yperen, Hagedoorn, \& Geurts, 1996). In a similar research Schwarzwald, Koslowsky, and Shalit (1992) argued that employees expecting to promoted, but ignored by organization has a tendency to absent. Furthermore researches perceived that the relationship between organizational deviance and job satisfaction depends on each other.

Some researchers found that lack of job satisfaction is one of the main motivations for an employee to dysfunction or steal at work place (Kulas et al., 2007). According to Judge job satisfaction and deviance in the organization are negatively related to each other (Judge, Scott, \& Ilies, 2006). Based on recent research there Is negative relationship between job satisfaction and workplace deviance (De Roeck \& Maon, 2018). One of the latest research shown the major influence of workplace deviant behavior through job satisfaction (Mahyarni, 2019). Hypothesis 2: There is a negative relationship between job satisfaction and workplace deviance.

\subsection{Organizational Justice and Job Satisfaction}

There are many research on organizational justice and its positive relationship with job satisfaction, and organizational justice (Folger and Konovsky, 1989; McFarlin and Sweeney, 1992). With organizational justice, if the employees are pleased or displeased with the organization, it gives them motivation to strive hard and lead to a decrease in dysfunction of employee in the workplace. Some researcher found that in each organization the level of job satisfaction of staff can create a pleasant environment in the workplace and higher outcome to enhance the productivity and efficiency of employees also there are some research that shows the positive relationship between 
organizational justice and job satisfaction (McFarlin \& Sweeney, 1992).

Based on research of Fatt, Khin, and Heng (2010) it is proven that the correlation between organizational justice and job satisfaction is positive and influential. Some research show that in an organization that have concern about organizational justice, the satisfaction of employees in their job is high and the loyalty and productivity of employees are enhanced in the organization (McFarlin \& Sweeney, 1992). When employees are treated by supervisors with trust and fairness and let them have more commitment to the organization, employee job satisfaction is enhanced (Walumbwa, Wu, \& Orwa, 2008).

Many researchers emphasized the correlation of injustice and job satisfaction mostly in the outcomes of the organization. They deduce that sometimes unfairness in the workplace creates the sense of betrayal from the organization in the employees mind which have an impact on their efficiency and productivity and they feel hardly satisfied with this situation (Walumbwa et al., 2008). Based on similar research, it is proven that the correlation between organizational justice and job satisfaction is positive and influential. Based on the empirical evidences that have been presented above the following hypotheses are advanced (Fatt et al., 2010). The analysis shown, a lower level of organizational justice leads to more deviance, and the mediating effect of job satisfaction was also significant (Kim \& Chung, 2019).

Hypothesis 3: There is a negative relationship between organizational justice and job satisfaction.

\subsection{Job Satisfaction Mediating Effect}

One of the main factors that enhance efficiency and success of employees in the workplace is job satisfaction, which is more dependent on human resource management in the organization (Crossman \& Abou-Zaki, 2003). Based on the work of Ladebo (2008) it can be concluded that the role of appropriate environment of the workplace and respect to the employees' impact on increasing employees 'satisfaction and bring the organization productivity. On the other hand, dissatisfied respondents tend to cite extrinsic factors such as supervision, pay, company policies and working condition. Moreover, research has suggested that job dissatisfaction is related to measures of deviant behaviors (Bennett \& Robinson, 2000). Likewise, Dalal (2005) and Judge (2001) obtained a negative correlation between job satisfaction and workplace deviance in their studies. One of the latest analysis shown that the mediation model is statistically significant.

Organizational justice showed a higher frequency of deviance with the mediating effect of job satisfaction was also significant(Kim \& Chung, 2019).

Hypothesis 4: Job satisfaction mediates the relationship between organizational justice and workplace deviance.

\subsection{Research Framework}

As it is illustrated in Figure 1.1 the relationship between the organizational justice, job satisfaction and workplace deviance is shown. This framework is designed according to the literature review that job satisfaction is the mediator and workplace deviance is the dependent variable.

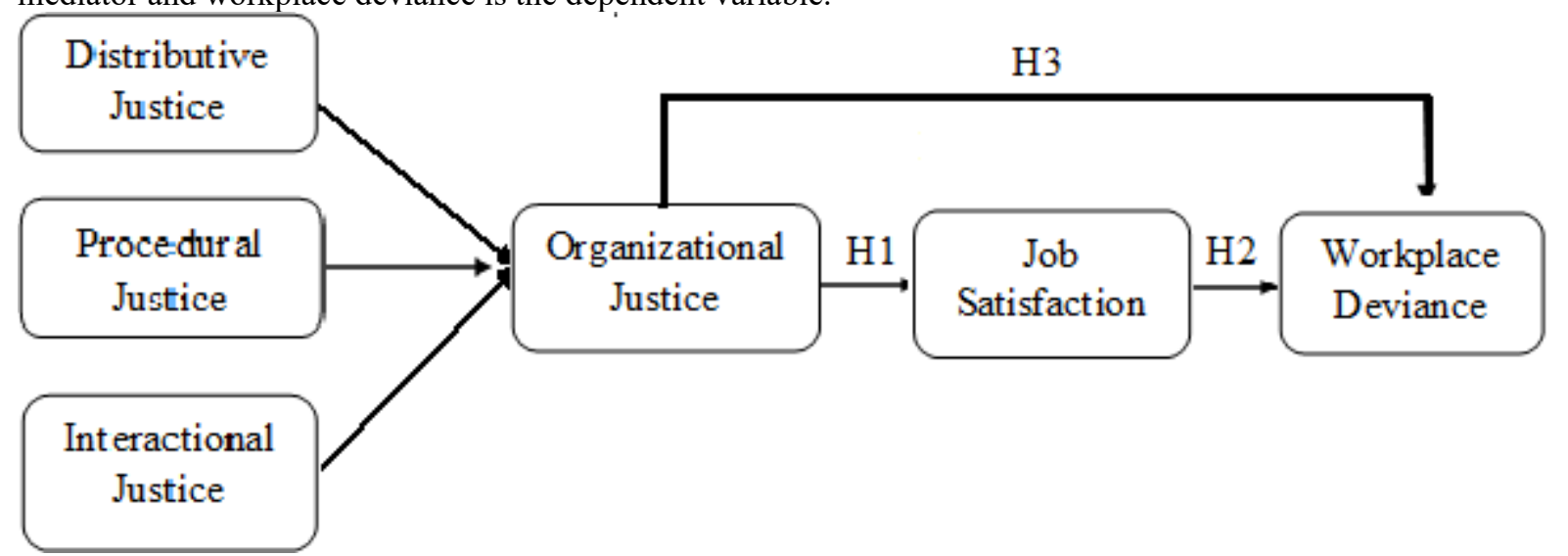

Figure 1.1: Conceptual Framework

\section{Methods}

\subsection{Sample Procedures}

Simple random sampling was used in this research. The target population of this research is selected small and medium enterprises (SMEs) employees in Malaysia. There are approximately 20,000 SME companies in Malaysia. The researchers emailed 143 questionnaire and 103 responses were received. This research is conducted among all employees who work in SMEs Malaysia.

This study focused on deviance in the organization that might be affected by organizational justice and job satisfaction. The independent variable for this research would be organizational justice. The mediating variable 
would be job satisfaction and the dependent variable is workplace deviance. The questionnaire of this study is prepared based on prior research on organizational justice, job satisfaction and workplace deviance.

In this research the impact of organizational justice and job satisfaction on workplace deviance is examined. The questionnaires were distributed randomly to the employees from different industries in Malaysia. From the 140 online questionnaires, 103 responses were received.

\subsection{Measures}

Based on the review of workplace deviance, a total of 47 questions were used in this research. Eighteen questions were adopted from the (Colquitt et al., 2001), five questions were adopted from (Brayfield \& Rothe, 1951), and 10 questions were taken from (Smith \& McCardle, 1998) with some modification. Basically, the questionnaire was divided into two group sections: demographic section and main section. The questionnaire was written in English. Section A focused on the demographic profile of the respondents. This section covered the background of company, year of establishment, number of employees, background of respondents including sex, age, marital status, race, education level, educational background, years of working experience, and length of service with the current organization, position, and year of last promotion in the organization. Section B consisted of three parts that include 35 questions. This part measures distributive justice, procedural justice, international justice, job satisfaction and workplace deviance. This section is divided into three parts based on the conceptual framework. Section B1: distributive justice four questions; procedural justice seven questions; interactional justice nine questions.

Section B2: five questions on job satisfaction.

Section B3: ten questions on workplace deviance.

The Likert scale was used in this research and asked respondents to rate each statement from strongly disagree to strongly agree. Likert scale was used in this study to generate statistical measurement of the impact of organizational justice and job satisfaction on workplace deviance. According to Sekaran (2009), the Likert scale is commonly used in the questionnaire survey. The responses over a number of items tapping a particular concept or variable can be analyzed item by item, but it is also possible to calculate a total or summated score for each respondent by summing across items. The summated approach is widely used, and therefore the Likert scale is also referred to as a smoothed scale.

\section{Results}

This study investigated the mediate of job satisfaction among organizational justice and workplace deviance in organization between Malaysian employees. In this section will presents the reporting of the results of this exploratory study arranged in context to the research objective from the questionnaire that following themes were found. In this section will explain the results of the data analysis. The ultimate goal is to declare the findings of the study. Therefore, the aim of this part is to test the hypotheses and give the results of the data analyses in detail to provide a guiding tool to human resource managers and decision makers.

\subsection{Exploratory Factor Analysis (EFA)}

Exploratory factor analysis (EFA) and principal components analysis (PCA) both are methods that are used to help investigators represent a large number of relationships among interval-level variables in a simpler (more parsimonious) way (Leech, Barrett, \& Morgan, 2008). In current study, Exploratory Factor Analysis (EFA) using principal component analysis has been used in order to data reduction or detecting "misfit" variables. This is all because this sought to determine which, of a fairly large set of items, "hang together" as a group, or are answered most similarly by the participants. Further, Communality, Kaiser-Meyer-Olkin (KMO) and factor loadings will be presented.

\subsection{Communality}

Communality is the study of the extent to which an item correlates with all other items. Higher communalities are better. If communalities for a particular variable are low $(<0.6)$, then that variable will struggle to load significantly on any factor. In that case, the variables must be dropped from the list of items.

\subsection{Exploratory Factor Analysis for Dependent and Mediator Variables}

The assumption of independent sampling was met. The assumption of normality, linear relationships between pair of variables, and the variables being correlated at a moderate level (as it is presented in Table 4.11 the KMO's measure of adequacy for both dependent and mediator are greater than 0.7 and Bartlett's Test of Sphericity for both is significant) were checked. Items of each construct have been checked each at a time. Principal component was selected considerd as the extraction method. In terms of rotation, Direct Oblimin was chosen and finally items with loading less than 0.6 were omitted from each construct. Tables 1.1 and 1.2 displays the items and factor loadings for the rotated factors, with loading less than 0.6 omitted to improve clarity. 
Table 1.1: Result of EFA on Workplace Deviance

\begin{tabular}{|l|c|c|}
\hline \multicolumn{2}{|c|}{ Workplace Deviance } \\
\hline \multicolumn{1}{|c|}{ Factor/item } & 0.933 \\
\hline Kaiser-Meyer-Olkin Measure of Sampling Adequacy. & 781.039 (sig 0.000 df =28) \\
\hline Bartlett's Test of Sphericity & Cumulative Variance: $75.62 \%$ \\
\hline Eigenvalue: 6.050 & loading & Communalities \\
\hline \multicolumn{1}{|c|}{} & .934 & .872 \\
\hline DV6: I intentionally worked slower than I could. & .901 & .812 \\
\hline DV10: I put little effort in my work. & .890 & 793 \\
\hline $\begin{array}{l}\text { DV5: Discussed confidential company information with an unauthorized } \\
\text { person. }\end{array}$ & .867 & .752 \\
\hline DV4: Spend too much time fantasizing or daydreaming instead of working. & .866 & .750 \\
\hline DV7: I neglected to follow my manager's instruction. & .845 & .714 \\
\hline DV8: I take longer break than is acceptable at work. & .842 & .709 \\
\hline DV9: Falsified a receipt to get more money for work related expenses. & .805 & .648 \\
\hline DV3: I take merchandize from work without permission. & & .953 \\
\hline Internal consistency reliability (Cronbach's alpha) & & \\
\hline
\end{tabular}

Table 1.2: Result of EFA on Job Satisfaction

\begin{tabular}{|l|c|c|}
\hline \multicolumn{1}{|c|}{ Item } & \multicolumn{2}{c|}{ Value } \\
\hline Kaiser-Meyer-Olkin Measure of Sampling Adequacy. & 0.819 \\
\hline Bartlett's Test of Sphericity & \multicolumn{2}{c|}{259.525 (sig 0.000 df =6) } \\
\hline Eigenvalue: 3.108 & Cumulative Variance: $77.71 \%$ \\
\hline \multicolumn{1}{|c|}{ Factor/item } & loading & Communalities \\
\hline JS3: I like my job better than the average worker does. & .893 & .797 \\
\hline JS4: I find real enjoyment in my job. & .893 & .797 \\
\hline JS1: I am very satisfied with my job. & .885 & .783 \\
\hline JS2: Most days I am enthusiastic about my job. & .855 & .731 \\
\hline
\end{tabular}

\subsection{Exploratory Factor Analysis for Independent Variables}

The assumption of independent sampling was met. The assumption of normality, linear relationships between pair of variables, and the variables being correlated at a moderate level (as it is presented in Table 1.1the KMO's measure of adequacy for all three independent variables are greater than 0.7 and Bartlett's Test of Sphericity for all is significant) were checked. Items of each construct have been checked each at a time. Principal component was selected considered as extraction method. In terms of rotation, Direct Oblimin was chosen and finally items with loading less than 0.6 were omitted from each construct. Table 1.3 displays the items and factor loadings for the rotated factors, with loading less than 0.6 omitted to improve clarity. 
Table1.3: Result of EFA on Organizational Justice dimensions

\begin{tabular}{|c|c|c|}
\hline \multicolumn{3}{|l|}{ Distributive Justice } \\
\hline Kaiser-Meyer-Olkin Measure of Sampling Adequacy. & \multicolumn{2}{|l|}{0.853} \\
\hline Bartlett's Test of Sphericity & \multicolumn{2}{|c|}{$295.380(\operatorname{sign} 0.000 \mathrm{df}=6)$} \\
\hline Eigenvalue: 3.23 & \multicolumn{2}{|c|}{ Cumulative Variance: $80.82 \%$} \\
\hline Factor/item & loading & Communalities \\
\hline DJ1:The (outcome) I received reflects the effort I have put into my work. & .915 & .837 \\
\hline $\begin{array}{l}\text { DJ3: The (outcome) I received reflects what I have contributed to the } \\
\text { organization. }\end{array}$ & .904 & .818 \\
\hline DJ4: The (outcome) I received is justified given my performance. & .897 & .805 \\
\hline DJ2: The (outcome) I received is appropriate for the work I have completed. & .879 & .773 \\
\hline \multicolumn{3}{|l|}{ Procedural Justice } \\
\hline Kaiser-Meyer-Olkin Measure of Sampling Adequacy. & \multicolumn{2}{|l|}{0.898} \\
\hline Bartlett's Test of Sphericity & \multicolumn{2}{|c|}{$573.930(\operatorname{sign} 0.000 \mathrm{df}=21)$} \\
\hline Eigenvalue: 5.130 & \multicolumn{2}{|c|}{ Cumulative Variance: $73.28 \%$} \\
\hline Factor/item & loading & Communalities \\
\hline $\begin{array}{l}\text { PJ1: I have been able to express my views and feelings during the procedures } \\
\text { used to arrive at the (outcome). }\end{array}$ & .875 & .765 \\
\hline $\begin{array}{l}\text { PJ3: The procedures used to arrive at the (outcome) have been applied } \\
\text { consistently. }\end{array}$ & .868 & .753 \\
\hline PJ4: The procedures used to arrive at the (outcome) have been free of bias. & .864 & .747 \\
\hline $\begin{array}{l}\text { PJ5: The procedures used to arrive at the (outcome) are based on accurate } \\
\text { information. }\end{array}$ & .863 & .744 \\
\hline $\begin{array}{l}\text { PJ7: The procedures used to arrive at the (outcome) have upheld ethical and } \\
\text { moral standards. }\end{array}$ & .857 & .735 \\
\hline PJ2: I have an influence over the (outcome) arrived at by the procedures used. & .848 & .719 \\
\hline PJ6: I have been able to appeal the (outcome) arrived at by those procedures. & .817 & .668 \\
\hline \multicolumn{3}{|l|}{ Interactional Justice } \\
\hline Kaiser-Meyer-Olkin Measure of Sampling Adequacy. & \multicolumn{2}{|l|}{0.920} \\
\hline Bartlett's Test of Sphericity & \multicolumn{2}{|c|}{$888.726($ sign $0.000 \quad \mathrm{df}=36)$} \\
\hline Eigenvalue: 6.655 & \multicolumn{2}{|c|}{ Cumulative Variance: $73.94 \%$} \\
\hline Factor/item & loading & Communalities \\
\hline IJ1: (He/She) has treated me in a polite manner. & .906 & .820 \\
\hline $\begin{array}{l}\text { IJ9: (He/She) seemed to tailor (his/her) communications to individuals' } \\
\text { specific needs. }\end{array}$ & .892 & .795 \\
\hline IJ2: (He/She) has treated me dignity. & .878 & .771 \\
\hline IJ3: (He/She) has treated me with respect. & .872 & .761 \\
\hline IJ5: (He/She) has been honest in (his/her) communication with me. & .861 & .742 \\
\hline IJ7: (His/her) explanations regarding the procedures were reasonable. & .859 & .739 \\
\hline IJ6: (He/She) has explained the procedures thoroughly. & .848 & .719 \\
\hline IJ8: (He/She) has communicated details in a timely manner. & .822 & .675 \\
\hline IJ4: (He/She) has refrained from improper remarks or comments. & .796 & .633 \\
\hline
\end{tabular}

\subsection{Test of Mediating}

To test the hypothesis that job satisfaction mediates the effect of distributive justice (H1), procedural justice, interactional justice, on workplace deviance, three regression models were estimated. Following Baron and Kenny (1986), model 1, regressing job satisfaction on distributive justice, procedural justice, interactional justice; model 2, regressing workplace deviance on distributive justice, procedural justice, interactional justice; and model 3, regressing workplace deviance on distributive justice, procedural justice, interactional justice, and job satisfaction.

Separate coefficients for each equation were estimated and tested. As Sekaran and Bougie (2010) suggested, to establish mediation the following conditions must hold

1) Distributive justice, procedural justice, and interactional justice must affect job satisfaction in model 1.

2) Distributive justice, procedural justice, and interactional justice must be shown to impact workplace deviance in model 2 .

3) Distributive justice, procedural justice, and interactional justice must affect workplace deviance in model 3 (while controlling for Job satisfaction).

If these conditions all hold in the predicted direction, then the effect of distributive justice, procedural justice, 
and interactional justice must be less in model 3 than in model 2. Perfect mediation holds if distributive justice, procedural justice, and interactional justice have no effect when the effect of job satisfaction is controlled for (model 3).

The adjusted $\mathrm{R}$ square of the first regression model (model 1) was 0.853 and the model was statistically significant. In this model, interactional justice and distributive justice were significant predictors of job satisfaction at 0.001 level of significance whereas the impact of procedural justice on job satisfaction was insignificant. This indicates that only distributive justice and interactional justice affected job satisfaction. The adjusted R square of the second regression model (model 2) was 0.645 and this model was also statistically significant. Model 2, as depicted in Table 1.3, indicated interactional justice was significant predictors of workplace deviance significance, whereas distributive justice and procedural justice were significant predictors only at 0.10 or 10 percent level of significance. The adjusted R square of the last model (model 3) was 0.653 and again the model was statistically significant.

Interactional justice became insignificant predictor of workplace deviance when job satisfaction was controlled for. The effect of interactional justice on workplace deviance was insignificant in the third model in comparison to the second model. Thus, all conditions for perfect (full) mediation were met for interactional justice. In terms of distributive justice, in model 1 it had strong and significant influence on job satisfaction whereas such influence of distributive justice on workplace deviance have been found at 0.05 . Thus it can be concluded distributive justice had indirect effect on workplace deviance. However, if the impact of distributive justice on workplace at 0.1 level of significant might be considered as a salient influence, this influence in model 3 also has become insignificant after controlling for job satisfaction in model. Thus, similarly conditions for perfect (full) mediation were met for distributive justice at 0.10 level of significance. Finally, it was found that procedural justice was not related to job satisfaction, and only at 0.10 level of significance influenced workplace deviance (when it has been controlled for job satisfaction). Therefore, hypothesis 1 (H1), has been supported for two out of three dimensions of organizational justice.

Table1.4 Hypothesis analysis

\begin{tabular}{|c|c|c|c|c|c|c|c|c|}
\hline \multicolumn{9}{|c|}{ Step1 model, with job satisfaction as the dependent variable } \\
\hline Model & Variables & Beta & $\mathrm{t}$ & $\mathrm{P}$ & $\mathrm{R} 2$ & Adjusted R2 & $\mathrm{F}$ & Sig. F \\
\hline \multirow[t]{4}{*}{1} & (Constant) & & .266 & .791 & 0.858 & 0.853 & 198.779 & 0.000 \\
\hline & Distributive Justice & $.426 * * *$ & 5.232 & .000 & & & & \\
\hline & Procedural Justice & -.006 & -.065 & .948 & & & & \\
\hline & Interactional Justice & $.547 * * *$ & 6.560 & .000 & & & & \\
\hline \multicolumn{9}{|c|}{ Model Fit $=0.853$} \\
\hline \multicolumn{9}{|c|}{ Step2 model, with Workplace deviance as the dependent variable } \\
\hline Model & Variables & Beta & $\mathrm{t}$ & $\mathrm{P}$ & $\mathrm{R} 2$ & Adjusted R2 & $\mathrm{F}$ & Sig. F \\
\hline \multirow[t]{4}{*}{2} & (Constant) & & 22.347 & .000 & 0.656 & 0.645 & 62.798 & 0.000 \\
\hline & Distributive Justice & -.226 & -1.782 & .078 & & & & \\
\hline & Procedural Justice & -.270 & -1.787 & .077 & & & & \\
\hline & Interactional Justice & $-.353 * *$ & -2.717 & .008 & & & & \\
\hline
\end{tabular}

Model Fit $=0.645$

Step3 model, including Job satisfaction as an independent variable and with Work-Place Deviance as the dependent variable

\begin{tabular}{|c|c|c|c|c|c|c|c|c|}
\hline $\begin{array}{l}\text { Model } \\
3\end{array}$ & $\begin{array}{l}\text { Variables } \\
\text { (Constant) }\end{array}$ & Beta & $\begin{array}{l}\mathrm{t} \\
22.649\end{array}$ & $\begin{array}{l}\mathrm{P} \\
.000\end{array}$ & $\begin{array}{l}\mathrm{R} 2 \\
0.667\end{array}$ & $\begin{array}{l}\text { Adjusted R2 } \\
0.653\end{array}$ & $\begin{array}{l}\mathrm{F} \\
49.038\end{array}$ & $\begin{array}{l}\text { Sig. F } \\
0.000\end{array}$ \\
\hline & Distributive Justice & -.106 & -.747 & .457 & & & & \\
\hline & Procedural Justice & -.272 & -1.819 & .072 & & & & \\
\hline & Interactional Justice & -.198 & -1.291 & .200 & & & & \\
\hline & Job Satisfaction & -.282 & -1.824 & .071 & & & & \\
\hline
\end{tabular}

Model Fit $=0.653$

Note. Parameters are standardized regression weights, with significance levels of t-values. Two sided tests. $\mathrm{N}=103$

Note:

A:Distributive justice has indirect effect on workplace, and this only via job satisfaction.

B:Procedural justice and distributive justice influence workplace deviance only at 0.1 level of significance.

C: At 0.1 level of significance job satisfaction fully mediates the relationship between distributive justice and workplace deviance.

Table 1.4 shows that interactional justice and distributive justice affect workplace deviance through job satisfaction. The managers would therefore be well advised to remedy inequities in the system to enhance the job satisfaction. Preventing or remedying deviance may require both individual and organizational change. To solve 
the problem of deviance, the top management may need to change the work environment and educate workers on how to adapt and cope better to the workplace.

\section{Conclusion}

One of the caveats of this study that should be taken into account would be a more diversified sample size. Therefore, a more diversified sample size is recommended for future researchers on this particular issue. In fact, from a sampling point of view, since procedural justice and distributive justice affected workplace deviance is only at 0.1 level of significance, increasing the sample size and more systematic sampling could make it clearer. Also, from a methodology standpoint, using of case studies and qualitative in the case of Malaysia evidently could be one of the recommendations for future research.

Results from this study show that interactional justice and distributive justice affect workplace deviance through job satisfaction. However, the influence of procedural justice on either workplace deviance or job satisfaction was not significant. Hence, if avoidance of deviance in workplace is a top priority for a manager, it is important to formulate policies and practices that help to enhance distributive and interactional justice perceptions. Whatever is done to improve employees' perceptions of justice will improve job satisfaction and thus help in preventing deviance at workplace.

\section{References}

Abbasi, A., \& Wan Ismail, W. K. (2018). Individual Predictors of Workplace Deviance with Mediating Effect of Job Satisfaction. European Journal of Business and Management, 10(14), 1-6.

Alexander, S., \& Ruderman, M. (1987). The role of procedural and distributive justice in organizational behavior. Social Justice Research, 1(2), 177-198.

Alias, Ismail, \& Abu Samah, B. (2013). Predictors of workplace deviant behaviour: HRD agenda for Malaysian support personnel. European Journal of Training and Development, 37(2), 161-182.

Alias, \& Rasdi, R. (2015). Organizational Predictors of Workplace Deviance among Support Staff. ProcediaSocial and Behavioral Sciences, 172, 126-133.

Baron, R. M., \& Kenny, D. A. (1986). The moderator-mediator variable distinction in social psychological research: conceptual, strategic, and statistical considerations. Journal of Personality and Social Psychology, $51,1173-1182$.

Bennett, R. J., \& Robinson, S. L. (2000). Development of a measure of workplace deviance. Journal of Applied Psychology, 85(3), 349.

Bennett, R. J., \& Robinson, S. L. (2003). The past, present, and future of workplace deviance research.

Berry, C. M., Ones, D. S., \& Sackett, P. R. (2007). Interpersonal deviance, organizational deviance, and their common correlates: a review and meta-analysis. Journal of Applied Psychology, 92(2), 410.

Blau, P. M. (1968). Social exchange. International encyclopedia of the social sciences, 7, 452-457.

Bodla, M. A., \& Danish, R. Q. (2009). Politics and Workplace: An Empirical Examination of the Relationship Between Perceived Organizational Politics and Work Performance. South Asian Journal of Management, 16(1).

Bouazzaoui, M., Wu, H.-J., Roehrich, J. K., Squire, B., \& Roath, A. S. (2020). Justice in inter-organizational relationships: A literature review and future research agenda. Industrial Marketing Management.

Brayfield, A. H., \& Rothe, H. F. (1951). An index of job satisfaction. Journal of Applied Psychology, 35(5), 307.

Chen, C.-T., \& King, B. (2018). Shaping the organizational citizenship behavior or workplace deviance: Key determining factors in the hospitality workforce. Journal of Hospitality and Tourism Management, 35, 1-8.

Cohen-Charash, Y., \& Spector, P. E. (2001). The role of justice in organizations: A meta-analysis. Organizational behavior and human decision processes, 86(2), 278-321.

Cole, M. S., Schaninger, W. S., \& Harris, S. G. (2002). The workplace social exchange network a multilevel, conceptual examination. Group \& Organization Management, 27(1), 142-167.

Colquitt, J. A., Conlon, D. E., Wesson, M. J., Porter, C. O., \& Ng, K. Y. (2001). Justice at the millennium: a metaanalytic review of 25 years of organizational justice research. Journal of Applied Psychology, 86(3), 425.

Colquitt, J. A., Scott, B. A., Judge, T. A., \& Shaw, J. C. (2006). Justice and personality: Using integrative theories to derive moderators of justice effects. Organizational Behavior and Human Decision Processes, 100(1), $110-127$.

Conlon, D. E., Meyer, C. J., \& Nowakowski, J. M. (2005). How does organizational justice affect performance, withdrawal, and counterproductive behavior?

Cote, S., \& Heslin, P. (2003). Job Satisfaction and Organizational Commitment. International Journal of Social Sciences, $9(1)$.

Cropanzano, R., \& Folger, R. (1991). Procedural justice and worker motivation. Motivation and work behavior, 5 , 131-143.

Cropanzano, R., Rupp, D. E., Mohler, C. J., \& Schminke, M. (2001). Three roads to organizational justice. 
Research in personnel and human resources management, 20, 1-113.

Crossman, A., \& Abou-Zaki, B. (2003). Job satisfaction and employee performance of Lebanese banking staff. Journal of Managerial Psychology, 18(4), 368-376.

Dalal, R. S. (2005). A meta-analysis of the relationship between organizational citizenship behavior and counterproductive work behavior. Journal of applied psychology, 90(6), 1241.

De Roeck, K., \& Maon, F. (2018). Building the theoretical puzzle of employees' reactions to corporate social responsibility: An integrative conceptual framework and research agenda. Journal of business ethics, $149(3)$, 609-625.

Everton, W. J., Mastrangelo, P. M., \& Jolton, J. A. (2005). Personality correlates of employees' personal use of work computers. CyberPsychology \& Behavior, 8(2), 143-153.

Faheem, M. A., \& Mahmud, N. (2015). The Effects of Organizational Justice on Workplace Deviance and Job Satisfaction of Employees: Evidence from a Public Sector Hospital of Pakistan. Mediterranean Journal of Social Sciences, 6(5), 342.

Fatt, C. K., Khin, E. W. S., \& Heng, T. N. (2010). The impact of organizational justice on employee's job satisfaction: The Malaysian companies perspectives. American Journal of Economics and Business Administration, 2(1), 56-63.

Gerlach, G. I. (2019). Linking justice perceptions, workplace relationship quality and job performance: The differential roles of vertical and horizontal workplace relationships. German Journal of Human Resource Management, 33(4), 337-362.

Greenberg. (1990). Organizational justice: Yesterday, today, and tomorrow. Journal of management, 16(2), 399432.

Greenberg, J. (1990). Organizational justice: Yesterday, today, and tomorrow. Journal of management, 16(2), 399432.

Guh, W.-Y., Lin, S.-P., Fan, C.-J., \& Yang, C.-F. (2013). Effects of organizational justice on organizational citizenship behaviors: Mediating effects of institutional trust and affective commitment. Psychological reports, $112(3), 818-834$.

H Hany, S., M Hassan, R., \& MM Badran, F. (2020). Relation between Organizational Justice and Workplace Deviance Behavior among Staff Nurses. Egyptian Journal of Health Care, 11(1), 248-259.

Hackman, J. R., \& Oldham, G. R. (1976). Motivation through the design of work: Test of a theory. Organizational behavior and human performance, 16(2), 250-279.

Judge, T. A., Scott, B. A., \& Ilies, R. (2006). Hostility, job attitudes, and workplace deviance: test of a multilevel model. Journal of Applied Psychology, 91(1), 126.

Judge, T. A., Thoresen, C. J., Bono, J. E., \& Patton, G. K. (2001). The job satisfaction-job performance relationship: A qualitative and quantitative review. Psychological bulletin, 127(3), 376.

Kim, S. J., \& Chung, E. K. (2019). The effect of organizational justice as perceived by occupational drivers on traffic accidents: Mediating effects of job satisfaction. Journal of safety research, 68, 27-32.

Kulas, J. T., McInnerney, J. E., DeMuth, R. F., \& Jadwinski, V. (2007). Employee satisfaction and theft: Testing climate perceptions as a mediator. The Journal of Psychology, 141(4), 389-402.

Ladebo, O. J., Awotunde, J. M., \& AbdulSalaam-Saghir, P. (2008). Coworkers' and supervisor interactional justice: Correlates of extension personnel's job satisfaction, distress, and aggressive behavior. Journal of Behavioral and Applied Management, 9(2), 1930-0158.

Leech, N. L., Barrett, K. C., \& Morgan, G. A. (2008). SPSS for Intermediate Statistics: Use and Interpretation (3rd ed.). New York: Lawrence Erlbaum Associate - Taylor and Francis Group, LLC.

Lugosi, P. (2019). Deviance, deviant behaviour and hospitality management: Sources, forms and drivers. Tourism Management, 74, 81-98.

Mahmud, N., Kenny, D. T., Zein, R. M., \& Hassan, S. N. (2015). The Effects of Office Ergonomic Training on Musculoskeletal Complaints, Sickness Absence, and Psychological Well-Being A Cluster Randomized Control Trial. Asia-Pacific Journal of Public Health, 27(2), NP1652-NP1668.

Mahyarni, M. (2019). The influence of spiritual leadership and its impacts on the reduction of workplace deviant behavior. International Journal of Public Leadership.

McFarlin, D. B., \& Sweeney, P. D. (1992). Research notes. Distributive and procedural justice as predictors of satisfaction with personal and organizational outcomes. Academy of Management Journal, 35(3), 626-637.

Ouyang, Z., Sang, J., Li, P., \& Peng, J. (2015). Organizational justice and job insecurity as mediators of the effect of emotional intelligence on job satisfaction: A study from China. Personality and Individual Differences, 76, 147-152.

Rice, D. B., Taylor, R., \& Forrester, J. K. (2020). The unwelcoming experience of abusive supervision and the impact of leader characteristics: turning employees into poor organizational citizens and future quitters. European Journal of Work and Organizational Psychology, 1-18.

Robbins, S., Judge, T. A., Millett, B., \& Boyle, M. (2013). Organisational behaviour: Pearson Higher Education 
AU.

Robinson, S. L., \& Bennett, R. J. (1995). A typology of deviant workplace behaviors: A multidimensional scaling study. Academy of Management Journal, 38(2), 555-572.

Rudman, L. A., Borgida, E., \& Robertson, B. A. (1995). Suffering in Silence: Procedural Justice Versus Gender Socialization issues in University Sexual Harassment Grievence Procedures. Basic and Applied Social Psychology, 17(4), 519-541.

Schwarzwald, J., Koslowsky, M., \& Shalit, B. (1992). A field study of employees' attitudes and behaviors after promotion decisions. Journal of applied psychology, 77(4), 511.

Sekaran, U., \& Bougie, R. (2010). Research Methods for Business - A Skill Building Approach (5th ed.). New York: John Wiley \& Sons.

Shore, L. M., Chung-Herrera, B. G., Dean, M. A., Ehrhart, K. H., Jung, D. I., Randel, A. E., \& Singh, G. (2009). Diversity in organizations: Where are we now and where are we going? Human resource management review, 19(2), 117-133.

Smith, J. E., \& McCardle, K. F. (1998). Valuing oil properties: integrating option pricing and decision analysis approaches. Operations Research, 46(2), 198-217.

Walumbwa, F. O., Wu, C., \& Orwa, B. (2008). Contingent reward transactional leadership, work attitudes, and organizational citizenship behavior: The role of procedural justice climate perceptions and strength. The Leadership Quarterly, 19(3), 251-265.

Yip, B., \& Rowlinson, S. (2009). Job redesign as an intervention strategy of burnout: Organizational perspective. Journal of Construction Engineering and Management, 135(8), 737-745.

Yperen, N. W., Hagedoorn, M., \& Geurts, S. A. (1996). Intent to leave and absenteeism as reactions to perceived inequity: The role of psychological and social constraints. Journal of Occupational and Organizational Psychology, 69(4), 367-372. 